Review

\title{
What about the Migrant Children? The State-Of-The-Art in Research Claiming Social Sustainability
}

\author{
Sidsel Boldermo ${ }^{1, *(1)}$ and Elin Eriksen Ødegaard ${ }^{2}$ (I) \\ 1 Department of Education, Faculty of Humanities, Social Sciences and Education, UiT, The Arctic University \\ of Norway, 9037 Tromsø, Norway \\ 2 KINDknow-Kindergarten Knowledge Centre for Systemic Research on Diversity and Sustainable Futures, \\ Faculty of Teacher Education, Arts and Sports, Western Norway University of Applied Sciences, \\ 5063 Bergen, Norway; elin.eriksen.odegaard@hvl.no \\ * Correspondence: sidsel.boldermo@uit.no; Tel.: +47-4810-8667
}

Received: 15 November 2018; Accepted: 4 January 2019; Published: 16 January 2019

\begin{abstract}
This study aimed to investigate research articles that relate to education for sustainability, primarily in early childhood, in order to describe to what extent a holistic perspective on education for sustainability has been applied, and how the social dimension is conceptualized. The review comprised research articles in Nordic Journals of Education, International Journals of Early Childhood Education, and International Journals of Education/Environmental/Sustainability education. The findings disclosed that researchers within the field of education for sustainability acknowledged, to a large extent, environmental, economic, and social aspects, and thus applied a holistic perspective. This review shows, however, that even if the social dimension were conceptualized as strongly related to topics such as social justice, citizenship, and the building of stable societies, few articles have investigated diversity, multicultural perspectives, or migrant children's situations in the context of early childhood education for sustainability. This review discloses that the concept of belonging is rarely used in connection to migrants and refugees in research on early childhood education for sustainability. A further argument encourages the inclusion of these aspects in further research which claims social sustainability.
\end{abstract}

Keywords: education for social sustainability; early childhood; migrant children; belonging

\section{Introduction}

As a demographic change is seen in many parts of the world, the issue of migrant children's experiences of belonging is a topic that needs to be addressed on the early childhood education agenda for sustainability. It is an urgent matter that the world community respect the United Nations Universal Declaration of Human Rights [1], as well as the Convention on the Rights of the Child [2]. Societies have the duty to protect and restore every child's right to live and to develop to his/her full potential. To create optimal conditions for migrant children, we believe that a holistic education is of the utmost importance in the most formative years, as also stated by the World Organization of Early Childhood Education, OMEP 2016 [3].

In this article, we understand education for sustainability as a process of social and cultural learning and, fundamentally, a value-based approach for developing new understandings and practices that give better conditions for all children. By sustaining equity, future generations' ability to live together in diverse societies will be nourished.

Crucial to our understanding is that we understand young children in light of their local cultural-historical heritage as well as understand that their childhood is happening now, as we speak. 
Future global and local work with sustainability will need to boost early childhood education for the simple reason that children spend their most formative years there. In early childhood educational institutions, families have tight bonds with their children and, therefore, most of them follow children's institutional lives with emotional interest. Research is evident when it comes to the crucial impact that a community has for children. It is indicated that being a part of a group of children in a new setting is of a great importance for children with an historical background of migration; however, children with an immigrant background can encounter challenges in experiencing belonging and positioning themselves within the kindergarten community $[4,5]$.

As outlined by Siraj-Blatchford [6], social sustainability concerns social, cultural and political issues affecting people's lives within and between nations. However, as just and inclusive societies are characterized, among other factors, by participation and solidarity, today's societies may have a way to go in developing such inclusive societies for all, as young children's self-understanding and future expectations are influenced by 'racial' equality and social class [6]. Substantive aspects such as social cohesion, inclusion, belonging and identity are central in defining social sustainability [7]. At the opposite end of the spectrum, social exclusion can be an impediment to social cohesion and social sustainability. As identified by OMEP 2016 [3], social exclusion constitutes a potential high-risk situation for migrant, refugee and asylum seeking children and their families, and it also weakens the common sense of belonging and identity that characterizes social cohesion [8].

By investigating what today's research in early childhood says about multicultural perspectives, diversity and belonging in the context of education for social sustainability, our study aims to contribute to new knowledge that can strengthen the perspective on social sustainability and support the situation for migrant and refugee children in early childhood institutions.

\subsection{Background: Education for Sustainability in Early Childhood}

Throughout the 1980s, the term Environmental Education was the international term used in debates on a growing concern for environmental issues that had occurred in the course of the 1960s and 1970s [9]. The Belgrade Charter (1975) [9] and The Tbilisi Declaration (1977) [10] aimed at the education of people, sought to pay attention to and work towards solutions of environmental problems and prevent new ones [10]. The Rio turning point and Agenda 21 in 1992 suggested a balance between the needs of the environment and the needs of humankind, and the Agenda 21 chapter 36 [11] also introduced and identified the Education for Sustainable Development as critical in order to promote sustainable development.

The terms Environmental Education, Education for Sustainable Development and Education for Sustainability are sometimes used interchangeably, and there are differences and tensions in how the terms are perceived. It has been argued that the turn from a focus on purely environmental issues within Environmental Education, towards more anthropocentric and pluralistic interpretations within Education for Sustainable Development, facilitates typically human needs such as human rights, democracy, and social issues at the expense of environmental issues [12]. Other researchers have claimed that Education for Sustainability, to a larger extent than Education for Sustainable Development, answers to the holistic perspective that acknowledges humanity's dependence on nature [13]. In this review, we do not take a stand on that particular issue; we prefer to use the term Education for Sustainability, and apply the UNESCO 2012 [14] meaning of the concept of Education for Sustainable Development-education for social transformation and with the goal of creating sustainable societies.

Education for sustainability aims to influence people's thinking and actions, and thereby contribute to sustainable decisions being taken. The UNESCO report, The contribution of early childhood to a sustainable society (2008) [15], concluded, among other conclusions, that early childhood education for sustainability is crucial as values, behavior and skills that are established in childhood may impact on choices and attitudes later in life. Further, the report pointed out that sustainability challenges us to move towards inclusive rather than segregated societies, and that a call for conceptualizations 
that strengthens interdependence, solidarity and justice was needed. The report Taking children seriously - how the EU can invest in early childhood education for a sustainable future (2011) [16], stated that even very young children are capable of advanced thinking in the context of social and environmental issues. Several researchers have thus advocated that, as a foundation for an understanding of sustainability is shaped in childhood, education for sustainable development should be emphasized in early childhood education [15,17-19].

After Julie Davis's [20] pioneering review on early childhood education for sustainability revealed that researchers within the context of education for sustainability generally did not include early childhood education in their research, and researchers within the field of early childhood generally did not investigate sustainability issues, two additional early childhood reviews on the subject have been conducted. Somerville and Williams [19] investigated whether there had been a change in focus on sustainable development in early childhood education research after Davis's (2009) review, and whether the research effort had increased. Somerville and Williams [19] did not investigate the social dimension in their study; however, the review from Hedefalk et al. [21] conceptualized the social dimension as involving justice, equality and a democratic approach [21]. Hedefalk et al.'s [21] review identified two different definitions of education for sustainability in early childhood education, i.e., it could be perceived as a threefold approach to education 'about', 'for' and 'in' the environment, and it included three interrelated dimensions-economic, social, and environmental. The authors pointed out that although both economic and social issues could cause unsustainable practices, they did not find any articles focusing on larger social issues related to sustainability. Hedefalk et al. thus questioned whether the social dimension was overlooked on the grounds that the focus on the environmental dimension overshadowed it [21].

\subsection{Research Topic and Aim: The Unexplored Field of Education for Social Sustainability}

In political as well as educational debates, a turn is seen in how sustainability is perceived, and an awareness of the differences in perceptions of the relationship between nature and society is crucial in the ongoing sustainability debate [22]. Traditionally, the understanding of sustainability and sustainability education is embedded within a three-pillar model where environmental, economic, and social aspects are interwoven $[17,23]$. As each aspect within the three-pillar model has developed independently, the interdependence and relationship between the three aspects, or dimensions, has not been sufficiently formulated, and one aspect in particular, the aspect of social sustainability, seems to lack a clear and coherent definition [23].

While issues such as global warming have been the dominant idea for a long time in the general worldwide sustainability debate and research, research into documenting the practice of environmental education has been the dominant area within early childhood sustainability research [24]. The field of early childhood educational research is currently focused on expanding the knowledge-base, elaborating upon what sustainability empirically means in early childhood education, and what it could look like in practice. This new research covers many aspects and dimensions of sustainability; nevertheless, it is often stated that the social dimensions of education for sustainability, which comprise questions regarding social justice and human rights, are less researched, compared to, for example, the ecological dimensions $[25,26]$. As elaborated, this is a fact also reflected through the findings in the review by Hedefalk et al. [21].

The social dimension of Education for Sustainability, as formulated by the UN, is about ensuring that all people have a good and just foundation for a decent life and have the opportunity to influence their own lives and the communities in which they live [27]. Social sustainability requires ethos of compassion and equality $[6,28]$, and can embrace a wide range of aspects, from the most general such as social justice and optimizing quality of life and well-being for future generations, to more specific goals such as enhancing people's democratic right to participate, take action, and influence their own lives in all institutions they are a part of. 
Eizenberg and Jabareen [23] approach social sustainability, among other approaches, within the concept of equity and diversity, where all members of a society, regardless of origin, race, ethnicity, gender, or color are permitted to participate in the society as peers. As social inclusion and the sense of community and belonging constitute social sustainability, different social or ethnic groups may be exposed to a lack of recognition and opportunities to participate in the society as equal citizens [23]. The concept of 'belonging' is introduced by Hägglund and Johansson [26] and grouped with the concept of 'values', and as an important concept within early childhood education for sustainability. Children's 'belonging' is related to their right to be involved, and linked to an identity as citizens, both in the local and the global context as world citizens. In children's peer cultures, the children's membership to the group is being continuously produced and re-produced [29], and the premises for social inclusion and belonging can be subject to negotiations, where characteristics such as age and gender can be used to legitimize exclusion $[26,30]$. Previous research has shown that migrant children and youth can be especially exposed to such experiences of outside-hood [4,31-33]. As children with the same social and cultural background often can share some kind of knowledge on how the world works [32], migrant children may be aware of the risk of being perceived as on the outside of a community to which they do not belong [4].

In the context of early education for sustainability, the issue of 'citizenship' is a value that is frequently emphasized $[19,26]$. In kindergarten, the children's experiences of 'citizenship' and of being included in the community can be related to their experience of belonging, regardless of race, ethnicity or origin [34,35]. As the demographic change in the European population is a fact, the issue of migrant children's experiences of citizenship and belonging is a topic that should be placed highly on the agenda in early childhood education for sustainability. In this review of the research literature in the field of Early Childhood Education for Sustainability, we seek to answer the call for additional research and conceptualization of social sustainability, and examine the concept of "belonging" within this context. Four research questions guided our study:

1. To what extent is a holistic and social perspective on sustainability applied/reflected in research articles regarding Early Childhood Education for Sustainability?

2. How is the social dimension of Education for Sustainability conceptualized by researchers in Early Childhood Education?

3. What does research say about diversity/multicultural perspectives and migrant children as related to the social dimension of Education for Sustainability?

4. What does research say about 'belonging' (and related concepts) in the context of Early Childhood Education for Sustainability?

Although our study investigated several of the same journals as the two aforementioned reviews by Somerville and Williams [19] and Hedefalk et al. [21], our review differs from those by our explicit focus on social sustainability, belonging and diversity. Our study's main conclusions revealed a lack of research on diversity, multicultural perspectives and migrant children's situations within the context of early childhood education for social sustainability. Additionally, although 'holistic' approaches were applied within the research articles, new questions were raised concerning what such approaches within the context of education for sustainability actually imply, as the content contained in the term 'holistic' varied.

\section{Materials and Methods}

In this literature review, only articles published in educational research journals were included, which means that books and book chapters have been excluded. Although the study primarily intended to focus on research within early childhood education, the review initially included other education journals as well. This was based on a wish to also include Nordic education journals in the review, and the number of Nordic journals that mainly focused on early childhood education was limited. 
Being aware of that, two other literature reviews on the issue of education for sustainability in early childhood education were conducted in 2015 [19,21]. These two reviews were included as research articles within the review in addition to being read as preparation before conducting this review. Since these two reviews have been conducted quite recently, the time span for this review was set as quite short, between 2013 and 2017/2018.

As both of the above mentioned reviews included the same research journals as Davis's [20] often-cited review, this review's first step comprised 12 of the same journals (both Nordic and international) included in Hedefalk et al.'s [21] work, with an additional 8 journals, of which 4 were Nordic. In other words, the total of 20 journals that were investigated within the timespan, comprised 9 Nordic journals and 11 international journals.

\subsection{Keywords and Selection of Articles}

The 20 journals were investigated by searching for keywords in the articles' titles, keywords, and/or abstracts. As the concept of 'belonging' is complex, dynamic, and multidimensional [30,36-38], we found it necessary to include terms that we considered related to (or elements of) 'belonging' within Education for Sustainability, such as 'citizenship' and 'agency'.

The keywords used in the search were sustainability, sustainable/environmental development, social sustainability, social dimension, belonging, citizenship, democracy, and agency. In the Nordic journals, the search was supplied with the same words in Norwegian and Swedish, in order to include articles written in those languages. Four of the journals of education had the term 'sustainable/sustainability or environmental' in their title, and, as a consequence, it was not essential that these terms should also be reflected in the article's titles, abstracts, or keywords. The search within these journals was, therefore, conducted in such a way that all titles and abstracts within the timeframe were read. Articles that only focused on nature/environment and, in addition, focused on children/youth above the age of 10, were excluded, while articles focusing on early childhood were included. Considering that one of the research questions was about finding out how social sustainability was conceptualized in research, almost all articles that conceptualized social sustainability were read and included, even if they were aimed towards youth/young adults.

A growing body of research that investigated children's voices and children's right to participation meant that several articles were found by searching the terms 'belonging', 'citizenship', and / or 'agency' in titles, keywords, or abstracts. These articles were read thoroughly in the first step of the review, in order to decide whether the articles mentioned or were aimed towards Education for Sustainability or Environmental Education, or whether the authors related the concepts to issues of sustainability, climate change, living in the Anthropocene, etc. If they did not comprise any such topics, they were excluded from the review.

\subsection{Procedure for Conducting the Review}

The review was conducted in four steps. The first step investigated the 20 journals as described above, resulting in a total of 59 articles that were relevant for further investigation. In the first step, the results disclosed that, in two of the chosen 20 journals-Journal of Early Childhood Research and Journal of Education for Sustainable Development-no relevant articles were found for the review within the chosen timeframe.

In step two, the 59 articles were read in order to decide whether the content was relevant for the review or not. Even if the review started with a very broad focus regarding the age group that the research articles investigated, choices had to be made along the way in order to both limit and expand the search towards answering the research questions. The first research question sought to determine to what extent a holistic approach was applied in research articles in early childhood. As a consequence, research articles that only focused on the environmental dimension and children above the age of 10 were excluded from the review. On the other hand, regarding the next research question which explored how the social dimension was conceptualized in early childhood research, we had to 
make some concessions as there was little research on this topic. As such, research articles that actually outlined or even investigated social sustainability were included, even if the age group in focus was above the aforementioned age or young adults, for example, Reis and Ferreira [39] and Miedema and Bertam-Troost [40]. As a result of reading and re-reading the articles, the final number of journals included was limited (See Table S1) and a total of 41 articles were considered relevant and were included in the final steps of the review (See Supplementary Materials-List of 41 articles included in the review).

After finishing step 2, the 41 articles were then read again and investigated thoroughly. As a third step, the articles were organized in feature maps [41] that highlighted the articles' main goals, research questions, applied theory, method, sample size, and conclusions. Articles that had been found in step 1 by using keywords such as 'belonging', 'citizenship', "democracy', or 'agency' (in English, Norwegian, or Swedish) also obtained an additional column in the feature map which specified how and to what extent the content of the article was linked to issues related to Education for Sustainability.

As a fourth and final step of the review, new feature maps were developed, this time in order to reveal how the content of the chosen articles related to the four research questions that guided the review. In this step, topics such as 'holistic' approach, social sustainability, diversity, multicultural perspectives, and migrant children were investigated. To establish an adequate overview on the feature maps in the third and fourth steps of the review, and in order to summarize and analyze the findings, a computer program for text analysis, Nvivo, was used. By creating and using nodes with keywords that reflected the content of the research questions, the computer program proved to be a useful tool to identify similarities and inequalities in the research material. The same method was also used to create an overview of the different methods used in the research articles.

\section{Results}

\subsection{Research in Education for Sustainability between 2013 and 2017/2018}

The 41 articles from the 14 journals investigated topics in a range from the teacher's competencies and interpretations regarding Education for Sustainability, the teacher's understandings of sustainability and the teacher's as well as the children's role in supporting social change and solving challenges of local and global patterns of unsustainable lifestyles, whether that be the issue of poverty and food security within the context of Education for Sustainability, nature play and children's lived experiences as global citizens, or explorations of educators conceptual understandings and pedagogical practices related to early childhood education for sustainability.

An interesting finding is the 'more-than-human' as a subject for investigation related to Education for Sustainability. Perspectives that focused on connectedness with nature, human-animal relations, common worlds, and relations with the more-than-human or non-human were found in Nordic and international articles alike [42-46]. Some articles even argued that the hegemonic way of understanding the relationship between the human and the more-than-human or non-human should be challenged in order to secure a global and holistic change for sustainability [45,47-49].

Another important finding worth noting is that the issue of children's agency was recurring in many of the articles, and children as agents for change and the need to listen to children's voices was described both in relation to environmental aspects as well as social aspects of sustainability [47-58].

\subsection{Application of a Holistic Perspective in Education for Sustainability}

A holistic perspective in Education for Sustainability was more or less applied in an overwhelming majority of the articles (36 of 41). At least three interdependent dimensions-environmental, economic, and social —were described in almost all of the articles, implicitly or explicitly, and, while some of them mainly related their research, findings, and discussions to the environmental dimension [59,60], a large proportion of the articles explicitly supported a socially critical and holistic informed perspective on Education for Sustainability $[21,40,48-52,54,56,57,61-66]$. 
Five of the articles (all from one North American journal), mainly used the term 'environmental education', but, as Iskos and Karakosta [67] described, the environment is perceived holistically with the inclusion of the natural, the artificial, the structured, the socio-economic, and the historical dimensions. Children's rights and children's voices were discussed as important issues related to environmental education [55], and Nugent and Beames [68] claimed that outdoor play could be a method for fostering socio-culturally responsive ways of thinking and caring. Reis and Ferreira [39] explored empowerment, participation, and children as responsible citizens as well as inclusion and social ties within communities. However, these articles applied an approach which revolved around nature- or outdoor-based activities with children in order to include children in environmental research, to achieve pro-environmental behaviors, children's awareness and care for the natural environment, or to strengthen their environmental identity and their sense of comfort and trust in nature.

Several of the articles argued that education for sustainability in early childhood was often being (mis)interpreted into a narrow focus on nature and outdoor play. The authors contended that there was much work to be done to extend the thinking and practice related to the education for sustainability beyond the environmental dimension, in order to embrace a more holistic perspective that also incorporates the social and cultural dimension. A greater focus on sociocultural issues like equality and justice and the negotiation of new approaches to link democratic values to issues of sustainability within education was called for $[49,50,52,58,61,69,70]$.

\subsection{Conceptualizations of the Social Dimension, Multicultural Perspectives, and Belonging}

The social dimension of Education for Sustainability was, to some extent, present in the vast majority of the articles, very often described within the explanation of the three interdependent dimensions of sustainability and conceptualized or emphasized in various ways. Recurring topics related to the understandings of the social dimension in the articles were democracy and democratic values, children's rights, citizenship, children as active citizens, and as participating agents of change $[49,50,52-54,61,62,66,70,71]$.

Other topics described as related to the social dimension were social participation, diversity, social and economic justice, human rights, equality, responsibility, and tolerance $[40,51,62,63]$.

Although various conceptualizations of the social dimension of Education for Sustainability were found in most of the investigated articles, only a few of them had an explicit and outspoken focus throughout the article with aims directed explicitly towards the social dimension, investigating children as agents of change for social sustainability and their agency as global citizens to affect social justice. Hammond et al. [51] adopted the term "social sustainability" in investigating children's perspectives on poverty, and they argued that working with children with Education for Sustainability and sustainable futures should involve working with social issues such as global citizenship, social justice, and human rights. Additionally, the articles of Reunamo and Suomela [62] and Miedema and Bertram-Troost [40] both conceptualized the social dimension of Education for Sustainability as related to global citizenship. Reunamo and Suomela [62] argued that the fundamental experiences of belonging, understanding, and agency are rooted in early childhood, and that the more warmth and concern children encounter, the more concretely they can feel their belonging within a shared, even global, society [62]. Miedema and Bertram-Troost [40] applied an explicit perspective on social sustainability when investigating challenges of global citizenship for a worldview education. Exemplifying the current global climate, they discussed the necessity to think and act more globally in both religious education and worldview education in order to prevent the development of narrow-minded or radicalized children and young people.

Issues of Education for Sustainability related to migrant children, multicultural aspects, or diversity were neither investigated nor outlined; however, the subject was identified as relevant in some of the articles $[39,40,50,56,61,62,66,70,72]$. Pramling Samuelsson and Park [50] considered that the diversity of cultural contexts in children's lives could be what sustainability might be all about. Sageidet [56] stated that Education for Sustainability as a pedagogical approach promoted a 
solidarity as well as a global perspective and could contribute to children's multicultural belonging. With reference to Dewey's pragmatist view, Miedema and Bertram-Troost [40] argued that there is a need for children to be confronted by and acquainted with other children's religious, cultural, ethnic, and economic backgrounds. Reis and Ferreira [39] included diversity and multicultural perspectives in their discussions revolving around inclusiveness and social ties within communities, and they also claimed that the sharing of experiences through social occasions, celebrations, and growing food could also help build a sense of belonging.

\subsection{Overview of the Methods Used in the Research Articles between 2013 and 2017/2018}

In the review, 15 of the 41 articles turned out to be based on literature studies and/or document analysis (See Tables S2 and S3 for overview of methods). Of these, 5 articles were empirically based on questionnaires or surveys sent to a large number of teachers, student teachers, and/or teacher educators, while an additional 3 articles were based on projects or workshops with teachers and/or student teachers, or teacher educators. Six articles were empirically based on data from interviews or focus group interviews with teachers, student teachers, and/or teacher educators. A total of 12 out of the 41 articles based their findings on research that included children: case studies/fieldwork together with children (4), larger workshops / projects with children as participants (5), interviews or dialogues with children (1), and observations (photo and video observations) of children (2). Of the 12 articles that included children in their research, 4 had an outspoken focus towards issues related to social sustainability.

\section{Discussion}

\subsection{The 'What' in 'Holistic'-What does 'Holistic' Actually Mean?}

The findings in this review reveal that the call for more holistic approaches towards Education for Sustainability has resulted in a growing body of research about such approaches, perhaps especially within the early childhood research context, where the majority of the articles in the review were incorporated within a holistic approach. Although the most regular way of applying a 'holistic' approach proved to be the inclusion of the three interdependent dimensions (environmental, social, and economic), our findings indicate that the 'holistic approach' implies different understandings of what 'holistic' in the context of education for sustainability might actually mean. While some articles claimed to advocate a holistic approach by including the three-pillar model and especially mentioned the social dimension, other articles mentioned artificial and historical dimensions. Several articles argued that a 'holistic approach' to education for sustainability should include the interdependence between humans and nature, the 'more-than-human' or nature as a co-constructor, and thus challenge the anthropocentric worldview. Such arguments can be understood in relation with the criticism of the transformation of the term Environmental Education into the term Education for Sustainable Development which, it has been argued, could be viewed as a product and carrier of globalizing forces [73] and as an anthropocentric turn that facilitates typically human needs at the expense of environmental issues [12]. Also, Seghezzo [22], who acknowledged the interdependence between humans, and between humans and nature, as a strong political tool, has criticized the common three-dimensional notion of sustainability, arguing that such a triangle formed by People (social), Planet (environment), and Profit/Prosperity (economy), forms an anthropocentric framework that comprises neither the interaction nor the interdependence between human aspects, space and time, and thus needs a re-examination.

\subsection{Diversity and Migrant Children's Situations within Education for Social Sustainability}

Even if diversity and multicultural aspects were, to a certain extent, subject for investigation in some of the articles, our review revealed that topics revolving around migrant children's situations and their experiences of belonging to communities or society have neither been particularly investigated 
nor discussed in the context of Early Childhood Education for Social Sustainability. Considering that the review has identified a growing body of research that discusses the importance of citizenship and children as active citizens, it is remarkable that migrant children's situations related to such citizenship through the experiences of social inclusion and belonging, have not been addressed.

\subsection{Children's Role in Research in Education for Social Sustainability}

More than a third of the articles included in the review proved to be based on literature studies and/or document analysis. Methodology was not a subject or category during the selection of articles, and this was, therefore, a random discovery. Somerville and Williams's [19] review criticized that studies within global discourses of children's rights tend to be characterized by advocacy rather than research that provides evidence for practice. The findings from our review provide a basis for additional critique, as a relatively small number of the articles included data from research with children. Rather, the research focus in the articles that were not based on literature studies tended to aim towards investigating teachers and educators' notions and experiences on how to work with education for sustainability with children. Thus, relatively few articles actually explored what education for sustainability with children might be.

The articles that researched aspects of social sustainability with children investigated children's theorizing of social justice, fairness, poverty, and social responsibility. This corresponded with the growing body of research that focuses on children as problem solvers, global citizens, and agents of change for sustainability. One article, however, posed a different, critical perspective on the reality of children's possibilities. Hedefalk [57] investigated children's interpretations in discussions of rules during play. Based on her findings, she questioned and problematized children's opportunities to critically discuss and evaluate, and, by that, actually be 'agents of change for sustainability'. She concluded that children, by and large, follow the rules set by the teacher, without questioning, and, therefore, have rather limited opportunities to evaluate whether the rules are reasonable or not. These are important reservations, which challenges the concept of children as problem solvers and agents of change for sustainability.

\section{Conclusions}

As a result of significant growth in research on Education for Sustainability within Early Childhood Education, it is clear that the call for holistic approaches has been met, as the majority of research articles incorporated or advocated such approaches to various extents. However, these findings formed the basis for additional questioning - what does a holistic approach within the context of education for sustainability actually mean? As this review started out with a perception of a holistic approach, implying that the social and economic dimensions are included together with the environmental dimensions, the findings proved that holistic approaches to education for sustainability could include many more aspects such as the interdependency between species, between humanity and the more-than-human, between humans and animals, between local and global issues, and between the individual and the society. These findings add to the ongoing debate on the content within 'education for sustainability' and correspond with Seghezzo's [22] call for alternative and expanded frameworks for the understanding of sustainability that include the interdependency between humans and between humans and nature. Additionally, Eizenberg and Jabareen's [23] suggestions of a new conceptual framework for social sustainability should be explored further within the context of education for sustainability in early childhood.

The literature review disclosed that a dominant route into social sustainability considers children as problem solvers. This is an optimistic, future-oriented perspective and reveals a view of the child as a competent child. However, we question whether this is too optimistic and gives too much credit to the child's competence. Such a view of the child also gives too much responsibility to children to solve problems of unsustainability. The politics of unsustainability is also governed by a community 
of adults, and responsibility to solve problems cannot be for children to bear on their own. As we see it, taking up issues of social sustainability should be a generational issue.

The most important finding in this review, as we perceive it, is the lack of particular and targeted research on migrant children's situations within the context of early childhood education for social sustainability. Through the analysis and discussion above, we have opened up an argument about critical engagement with the concept of diversity and multicultural aspects in research that connects to sustainability and early childhood. Furthermore, the findings create a greater awareness of the crucial importance of migrant children's experiences of belonging for future sustainable societies.

As this state-of-the-art literature reveals, alternative perceptions of what a holistic framework for Early Childhood Education for Sustainability might be create room for new understandings of how it should evolve in order to comprise migrant children's situations and perspectives, and their experiences of belonging to the local and the global society. Further research on education for social sustainability within the field of early childhood education is needed-in particular, research realizing the Convention on the Rights of the Child [2], encouraging practice-oriented research where human dignity and education for life, within the most formative years of a child, is a motivating driving force.

Supplementary Materials: The following are available online at http:/ / www.mdpi.com/2071-1050/11/2/459/ s1.

Author Contributions: Conceptualisation: S.B. and E.E.Ø. Data curation: S.B. Formal analysis: S.B. Funding acquisition: E.E.Ø. and S.B. Investigation: S.B. and E.E.Ø. Methodology: S.B. Project administration: S.B. Resources: S.B. and E.E.Ø. Software-Supervision: E.E.Ø. Validation: S.B. and E.E.Ø. Visualization-S.B. Writing一original draft preparation: E.E.Ø. and S.B. Writing-review and editing: S.B. and E.E.Ø.

Funding: This research was funded by UiT-The Arctic University of Norway, Western Norway University of Applied Sciences and Norges Forskningsråd, grant number 275575.

Conflicts of Interest: The authors declare no conflict of interest.

\section{References}

1. United Nations. Universal Declaration of Human Rights; United Nations: New York, NY, USA, 1948.

2. UNICEF. United Nations Convention on the Rights of the Child; UNICEF: New York, NY, USA, 1989.

3. Comité national canadien de l'Organisation Mondiale pour l'Éducation Préscolaire (OMEP). Declaration of the 68th OMEP World Assembly and Conference: Seoul, Korea, July 2016. Int. J. Early Child. 2016, 48, 387-389. [CrossRef]

4. Kalkman, K.; Clark, A. Here We Like "Playing" Princesses-Newcomer Migrant Children's Transitions within Day Care: Exploring Role Play as an Indication of Suitability and Home and Belonging. Eur. Early Child. Educ. Res. J. 2017, 25, 292-304. [CrossRef]

5. Sadownik, A. Belonging and participation at stake. Polish migrant children about (mis)recognition of their needs in Norwegian ECECs. Eur. Early Child. Educ. Res. J. 2018, 26, 956-971. [CrossRef]

6. Siraj-Blatchford, J. The implications of early understandings of inequality, science and technology for the development of sustainable societies. In The Contribution of Early Childhood Education to a Sustainable Society; Pramling Samuelson, I., Kaga, Y., Eds.; UNESCO: Paris, France, 2008.

7. Boström, M. A missing pillar? Challenges in theorizing and practicing social sustainability: Introduction to the special issue. Sustain. Sci. Pract. Policy 2012, 8, 3-14. [CrossRef]

8. Vasta, E. Do We Need Social Cohesion in the 21st Century? Multiple Languages of Belonging in the Metropolis. J. Intercult. Stud. 2013, 34, 196-213. [CrossRef]

9. UNESCO UNEP. The Belgrade Charter: A Framework for Environmental Education. In Proceedings of the International Workshop on Environmental Education, Belgrade, Serbia, 13-22 October 1975; UNESCO-UNEP: Paris, France, 1975.

10. United Nations Environment Programme. Intergovermental Conference on Environmental Education, Tbilsi, USSR; UNESCO-UNEP: Paris, France, 1978.

11. United Nations. Chapter 36-Promoting Education, Public Awareness and Training. In Proceedings of the United Nations Sustainable Development, United Nations Conference on Environment \& Development_-Agenda 21, Rio de Janerio, Brazil, 3-14 June 1992; United Nations: New York, NY, USA, 1993. 
12. Kopnina, H. Education for sustainable development (ESD): The turn away from 'environment' in environmental education? Environ. Educ. Res. 2012, 18, 699-717. [CrossRef]

13. Ärlemalm-Hagsèr, E.; Sundberg, B. Naturmöten och källsortering; en kvantitativ studie om lärande för hållbar utveckling i förskolan. Nordina (Elektronisk Ressurs) 2016, 12, 140-156. [CrossRef]

14. UNESCO. Shaping the Education of Tomorrow; UNESCO: Paris, France, 2012.

15. Pramling Samuelsson, I.; Kaga, Y. The Contribution of Early Childhood Education to a Sustainable Society; UNESCO: Paris, France, 2008.

16. Siraj-Blatchford, J.; Pramling Samuelsson, I.; Lenglet, F. Taking Children Seriously: How the EU can Invest in Early Childhood Education for a Sustainable Future. Int. J. Early Child. 2011, 43, 89. [CrossRef]

17. Siraj-Blatchford, J. Editorial: Education for Sustainable Development in Early Childhood. Int. J. Early Child. 2009, 41, 9-22. [CrossRef]

18. Ärlemalm-Hagsér, E.E. Engagerade i Världens Bästa? Lärande för Hållbarhet i Förskolan. Ph.D. Thesis, Faculty of Education, University of Gothenburg, Gothenburg, Sweden, 2013.

19. Somerville, M.; Williams, C. Sustainability education in early childhood: An updated review of research in the field. Contemp. Issues Early Child. 2015, 16, 102-117. [CrossRef]

20. Davis, J.M. Revealing the research 'hole' of early childhood education for sustainability: A preliminary survey of the literature. Environ. Educ. Res. 2009, 15, 227-241. [CrossRef]

21. Hedefalk, M.; Almqvist, J.; Östman, L. Education for Sustainable Development in Early Childhood Education: A Review of the Research Literature. Environ. Educ. Res. 2015, 21, 975-990. [CrossRef]

22. Seghezzo, L. The five dimensions of sustainability. Environm. Politics 2009, 18, 539-556. [CrossRef]

23. Eizenberg, E.; Jabareen, Y. Social Sustainability: A New Conceptual Framework. Sustainability 2017, 9, 68. [CrossRef]

24. Davis, J.M.; Elliott, S. (Eds.) An orientation to early childhood education for sustainability and research-Framing the text. In Research in Early Childhood for Sustainability. International Perspectives and Provocations; Routledge: New York, NY, USA, 2014.

25. Miller, M. Intercultural dialogues in early childhood education for sustainability. Embedding Indigenous perspectives. In Research in Early Childhood Education for Sustainability. International Perspectives and Provocations; Davis, J.M., Elliott, S., Eds.; Routledge: New York, NY, USA, 2014.

26. Hägglund, S.; Johansson, E. Belonging, value conflicts and childrens rights in learning for sustainability in early childhood. In Research in Early Childhood Education for Sustainability. International Perspectives and Provocations; Davis, J.M., Elliott, S., Eds.; Routledge: New York, NY, USA, 2014.

27. United Nations. United Nations Sustainable Development Goals; United Nations: New York, NY, USA, 2016.

28. Simonstein Fuentes, S. Education for peace in a sustainable society. In The Contribution of Early Childhood Education to a Sustainable Society; Pramling Samuelson, I., Kaga, Y., Eds.; UNESCO: Paris, France, 2008.

29. Yuval-Davis, N. Belonging and the politics of belonging. Patterns Prejud. 2006, 40, 197-214. [CrossRef]

30. Stratigos, T.; Bradley, B.; Sumsion, J. Infants, Family Day Care and the Politics of Belonging. Int. J. Early Child. 2014, 46, 171-186. [CrossRef]

31. Skattebol, J. Playing boys: The body, identity and belonging in the early years. Gender Educ. 2006, 18, 507-522. [CrossRef]

32. Winther-Lindqvist, D. Developing social identities and motives in school transitions. In Motives in Children's Development. Cultural-Historical Approaches; Hedegaard, M., Edwards, A., Fleer, M., Eds.; Cambridge University Press: Cambridge, UK, 2011; pp. 115-132.

33. Steen-Olsen, T. Cultural belonging and peer relations among young people in multi-ethnic Norwegian suburbs. Nord. Stud. Educ. 2013, 33, 314-328.

34. Nutbrown, C.; Clough, P. Citizenship and inclusion in the early years: Understanding and responding to children's perspectives on 'belonging'. Int. J. Early Years Educ. 2009, 17, 191-206. [CrossRef]

35. Juutinen, J. Inside or Outside? Small Stories about the Politics of Belonging in Preschools. Ph.D. Thesis, University of Oulu, Oulu, Finland, 2018.

36. Stratigos, T. Processes of categorisation and the politics of belonging in early childhood education and care: An infant's experience in multi-age family day care. Contemp. Issues Early Child. 2015, 16, 214-229. [CrossRef]

37. Sumsion, J.; Wong, S. Interrogating 'Belonging' in Belonging, Being and Becoming: The Early Years Learning Framework for Australia. Contemp. Issues Early Child. 2011, 12, 28-45. [CrossRef] 
38. Yuval-Davis, N.; Kannabiran, K.; Vieten, U. (Eds.) Introduction. Situated contemporary politics of belonging. In The situated politics of belonging; SAGE: London, UK; Thousand Oaks, CA, USA, 2006.

39. Reis, K.; Ferreira, J.-A. Community and School Gardens as Spaces for Learning Social Resilience. Can. J. Environ. Educ. 2015, 20, 63-77.

40. Miedema, S.; Bertram-Troost, G. The Challenges of Global Citizenship for Worldview Education. The Perspective of Social Sustainability. J. Teach. Educ. Sustain. 2015, 17, 44-52. [CrossRef]

41. Hart, C. Doing a Literature Review. Releasing the Social Science Research Imagination; Sage Publications: London, UK, 1998.

42. Barrett, M.J.; Harmin, M.; Maracle, B.; Patterson, M.; Thomson, C.; Flowers, M.; Bors, K. Shifting Relations with the More-than-Human: Six Threshold Concepts for Transformative Sustainability Learning. Environ. Educ. Res. 2017, 23, 131-143. [CrossRef]

43. Sjögren, H.; Gyberg, P.; Henriksson, M. Human-animal relations beyond the zoo: The quest for a more inclusive sustainability education. Pedagog. Cult. Soc. 2015, 23, 1-19. [CrossRef]

44. Taylor, A.; Pacini-Ketchabaw, V. Learning with children, ants, and worms in the Anthropocene: Towards a common world pedagogy of multispecies vulnerability. Pedagog. Cult. Soc. 2015, 23, 1-21. [CrossRef]

45. Sjögren, H. Den politisk-etiska potentialen hos djur-människorelationer i lärarutbildares samtal om hållbar utveckling. Pedagog. Forsk. Sver. 2014, 19, 90-109.

46. Liefländer, A.K.; Fröhlich, G.; Bogner, F.X.; Schultz, P.W. Promoting connectedness with nature through environmental education. Environ. Educ. Res. 2013, 19, 370-384. [CrossRef]

47. Weldemariam, K.; Boyd, D.; Hirst, N.; Sageidet, B.M.; Browder, J.K.; Grogan, L.; Hughes, F. A Critical Analysis of Concepts Associated with Sustainability in Early Childhood Curriculum Frameworks across Five National Contexts. Int. J. Early Child. 2017, 49, 333-351. [CrossRef]

48. Wals, A.E.J. Sustainability by Default: Co-Creating Care and Relationality through Early Childhood Education. Int. J. Early Child. 2017, 49, 155-164. [CrossRef]

49. Ärlemalm-Hagsér, E.; Elliott, S. Special Issue: Contemporary Research on Early Childhood Education for Sustainability. Int. J. Early Child. 2017, 49, 267-272. [CrossRef]

50. Pramling Samuelsson, I.; Park, E. How to Educate Children for Sustainable Learning and for a Sustainable World. Int. J. Early Child. 2017, 49, 273-285. [CrossRef]

51. Hammond, L.-L.; Hesterman, S.; Knaus, M. What's in Your Refrigerator? Children's Views on Equality, Work, Money and Access to Food. Int. J. Early Child. 2015, 47, 367-384. [CrossRef]

52. Hill, A.; Emery, S.; Nailon, D.; Dyment, J.; Getenet, S.; McCrea, N.; Davis, J.M. Exploring how adults who work with young children conceptualise sustainability and describe their practice initiatives. Australas. J. Early Child. 2014, 39, 14-22.

53. Ärlemalm-Hagsér, E.; Davis, J. Examining the Rhetoric: A Comparison of How Sustainability and Young Children's Participation and Agency are Framed in Australian and Swedish Early Childhood Education Curricula. Contemp. Issues Early Child. 2014, 15, 231-244. [CrossRef]

54. Eriksen, K.G. Why Education for Sustainable Development Needs Early Childhood Education: The Case of Norway. J. Teach. Educ. Sustain. 2013, 15, 107-120. [CrossRef]

55. Boileau, E.Y.S. Young Voices: The Challenges and Oppurtunities That Arise in Early Childhood Environmental Education Research. Can. J. Environ. Educ. 2013, 18, 142-154.

56. Sageidet, B.M. Bærekraftig utvikling i barnehagen-Bakgrunn og perspektiver. Norsk Pedagogisk Tidsskrift 2015, 99, 110-123.

57. Hedefalk, M. Barns möjligheter att utveckla en kritisk handlingsförmåga: En studie av meningsskapande i förskolans praktik. Utbildning Demokrati 2016, 24, 73-90.

58. Engdahl, I. Early Childhood Education for Sustainability: The OMEP World Project. Int. J. Early Child. 2015, 47, 347-366. [CrossRef]

59. Boyd, W. Playing cool: The sustainable Cool Cubby. Australas. J. Early Child. 2016, 41, 29-37.

60. Inoue, M.; O'Gorman, L.; Davis, J. Investigating Early Childhood Teachers' Understandings of and Practices in Education for Sustainability in Queensland: A Japan-Australia Research Collaboration. Aust. J. Environ. Educ. 2016, 32, 174-191. [CrossRef]

61. Korkmaz, A.; Guler Yildiz, T. Assessing preschools using the Eco-Schools program in terms of educating for sustainable development in early childhood education. Eur. Early Child. Educ. Res. J. 2017, 25, 595-611. [CrossRef] 
62. Reunamo, J.; Suomela, L. Education for Sustainable Development in Early Childhood Education in Finland. J. Teach. Educ. Sustain. 2013, 15, 91-102. [CrossRef]

63. Dyment, J.E.; Davis, J.M.; Nailon, D.; Emery, S.; Getenet, S.; McCrea, N.; Hill, A. The impact of professional development on early childhood educators' confidence, understanding and knowledge of education for sustainability. Environ. Educ. Res. 2013, 20,1-20. [CrossRef]

64. Straume, I. "Norge ligger på dette området langt fremme i forhold til de fleste land": Utdanning for bærekraftig utvikling i Norge og Sverige. Nordisk Tidsskrift Pedagogikk Kritikk 2016, 2, 78-96. [CrossRef]

65. Feriver, Ş.; Teksöz, G.; Olgan, R.; Reid, A. Training early childhood teachers for sustainability: Towards a 'learning experience of a different kind'. Environ. Educ. Res. 2015, 22, 1-30. [CrossRef]

66. Twigg, D.; Pendergast, D.; Twigg, J. Growing Global Citizens: Young Children's Lived Experiences with the Development of Their Own Social World. Int. Res. Early Child. Educ. 2015, 6, 79-91.

67. Iskos, E.; Karakosta, S. Not Just a Walk in the Park: Case Study of a Greek Preschool Located on an Educational Farm. Can. J. Environ. Educ. 2015, 20, 46-62.

68. Nugent, C.; Beames, S. Cultural Transmission at Nature Kindergartens: Foraging as a Key Ingredient. Can. J. Environ. Educ. 2015, 20, 78-91.

69. Pollock, K.; Warren, J.; Andersen, P. Inspiring environmentally responsible preschool children through the implementation of the 'national quality framework': Uncovering what lies between theory and practice. Australas. J. Early Child. 2017, 42, 12-19. [CrossRef]

70. Schmidt, C. Thrown Together: Incorporating Place and Sustainability into Early Literacy Education. Int. J. Early Child. 2017, 49, 165-179. [CrossRef]

71. Haas, C.; Ashman, G. Kindergarten children's introduction to sustainability through transformative, experiential nature play. Australas. J. Early Child. 2014, 39, 21.

72. Ärlemalm-Hagsér, E. Student Teachers' Workplace-Based Learning in Sweden on Early Childhood Education for Sustainability: Experiences in Practice Settings. Int. J. Early Child. 2017, 49, 411-427. [CrossRef]

73. Jickling, B.; Wals, A.E.J. Globalization and Environmental Education: Looking beyond Sustainable Development. J. Curric. Stud. 2008, 40,1-21. [CrossRef]

(C) 2019 by the authors. Licensee MDPI, Basel, Switzerland. This article is an open access article distributed under the terms and conditions of the Creative Commons Attribution (CC BY) license (http:/ / creativecommons.org/licenses/by/4.0/). 